\title{
Social Role and Gender Equality in the Gender Mainstreaming Era: The Meaning of Subjectivity Study of Female Students Perception in Jakarta State University
}

\author{
Wuri Handayani* \\ Communication Science \\ Universitas Negeri \\ Yogyakarta Yogyakarta, \\ Indonesia \\ wuri.handayani@uny.ac.id
}

\begin{abstract}
It is necessary to vary the meaning and extension of the legitimacy of the concept of traditional gender roles in gender discourse as the essence of gender equality. Gender equality that has been pursued through programs to empower women with the main aspects of economic income (in addition to education, health and political control) is in the dynamics of the strategic level. Based on a qualitative study of informants determined purposively as many as ten (10) female students in the college indicate that the perception of their social roles is progressive - "a new meaning" of traditional gender roles. The informant's subjectivity dominates the perception of their social role. With the method of critical - interpretative analysis (phenomenology), through in- depth interviews the informant does not prioritize economic aspects as a source of selfempowerment in his gender relations with men (husbands). Their discursive awareness determines the position of economic factors not as primary but under their traditional gender role which is educating and caring for children and the comfort of the household. Self-actualization is considered to be realized by more flexible ways of adjusting the role of the household. The role of educating and caring for these children is determined to consciously estimate and calculate the logical consequences. This paper encourages the need to increase and strengthen autonomy as a strategic criterion for Gender Equality policies. The principle of autonomy shows the high level of subjectivity and affection of women for their social (gender) roles, and the potential for democratic relations between men and women, the potential for gender equality.
\end{abstract}

Keywords-subjectivity, traditional gender roles, discursive awareness, gender equality, autonomy

\section{INTRODUCTION}

Subjectivity is important in the dynamics of the meaning of women's social roles which tends to be ignored. So far the expert opinion has made a generalization that to achieve gender equality, women have a socially supportive role structurally (increasing economic capacity). To achieve gender equality, the Government of the Republic of Indonesia integrates gender in development, with four strategies namely access, participation, control and benefits (Presidential Instruction Number 9 of 2000 concerning Gender Mainstreaming. Achieving gender equality in four aspects namely education, health and economic income, and control political. [1] Until now the impact of the implementation of the Policy has shown an increase in the educational attainment and employment of women. In the field of education, the University Higher Rough Participation Rate for 2018 is $28.34 \%$ and $32.09 \%$ for women and in 2019 for men $28.93 \%$ and $31.67 \%$ for women. [2] Female labor force participation rate in 2016-2019, have increased from $52,71 \%$ to $55,50 \%$. [3] With the inclusion of women on a large scale the workforce can be interpreted as increasing gender equality [4]. In terms of political control, in the 2009 Election the number of women who became members of the legislature was as much as $18 \%$ of the total members of the Legislative body. The 2014 general election was $17 \%$ and in 2019 it was $20.52 \%$. [5]

The data raises the meaning of the quantitative achievement of women's social roles in the public sphere as an indication of the progression of achieving gender equality. [6] However, the dynamics of the phenomenon indicate the complexity of the problem of women's social roles needs to be examined. Divorce cases increased from 2015 as many as 353,843 cases, 2016 as many as 365,654 cases, in 2017 as many as 374,516 cases, and 2018 as many as 408,202 cases.[7] If it is viewed more accurately, as many as $46.6 \%$ is due to the quarrels between husband and wife, then as many as $28.2 \%$ is due to the economic factors, as many as $18.2 \%$ is due to the leaving partner, and as many as $2.1 \%$ is caused by domestic violence.[8] Andreas stressed that divorce did not reject the possibility of being linked to or related to the impact of this phenomenon of mobilization (empowerment).[9] Furthermore, in terms of violence against women, the Child and Mother Protection Commission has reported that incest has 822 cases, rape has 792 cases, sexual intercourse has 503 cases, sexual abuse has 206, social exploitation has 137 , marital rape has 200 cases.[10] This data shows the importance of the women's social roles problem.

The dynamics of the problem of social roles, need to pay attention to aspects of women's subjectivity. Women's experience and knowledge are two very important 
substances in women's research. [11] According to Kabeer, in empowering the need for women to be able to make their own decisions about strategic choices around their lives, including in the realm of work.[1, p. 19].

The existed role social studies have reviewed the economic capacities and opportunities to increase the women wellbeing and potential. Nevertheless, dynamically, the result has not yet increased the women autonomy because of gender oppression. Hartini, explains the

economic empowerment is practical to eliminate the poverty. The generates of the various goodness characters of women existence is not as it should be, because of the patriarchy oppression.[12] In term of women's career (the state civil apparatus), the existence of educational access also women's skill has not indicated toward improvement, because the women do not have authority over the results of their efforts. They need to change the consciousness of the attitude of their social role concept and responsibility. [13] Ariane predicts that the phenomenon of the female labor force tends to stagnant in the context of economic growth and social change in Indonesia, which is considered not merely bad news. However, she acknowledges that there is an issue stated that the fundamental central has complicated women to participate, especially after having children[1]. Women also do not possess the women autonomy as stated in Tohri's research. It is mentioned that women perception is selfbeliefs which is pressed by the social- beliefs which makes women fail to understand their selves, so they are not able to defend. Women have been trapped in two perceptions of the beliefs of self and theology [14]

Some articles have implemented the women social role that women are used to be adhered by a factor of meaning by her man/husband, family and the social system. The researches also examine the experience of women live to confirm the determination of the informant social role in the perspective of gender, to obtain information about how gender give pressure and other factor which influence the strengthening of women social role subjectivity.

The research problem is formulated in three questions: 1) How informant perceives the women social roles; 2) what factors that emerge a "traditional women" perception (being a good woman either as mother also wife), and c) How informant perceived the role of gender that carries implications on potential program achievement of equality of gender.

\section{SOCIAL ROLE CONCEPTION: DYNAMIC, SUBJECTIVITY AND GENDER INTELLIGENCE}

Gender integration in development programs becomes women's mobilization area. So that, the women perception is fundamental. Perception is able to describe a view clearly, includes self-concept and its connection with the interpreted environment subjectively. [15]

The subjective approach in studying the social role of women is considered to contribute positively to the experience and knowledge of women, also to explore the complexity and layers of the problem that tend to be reduced by an objective approach. [11] Subjectivity underlines the how agents thinking process, explain and describe the world of social while ignoring the structures of objectivity [16]

Educational attainment becomes an important factor in the female self-quality development. Education shows how someone discovers the identity and existence of itself that is limited by the gender compulsion, also becomes the link to establish meaning, desire, and language. The values of humanity emphasize the depth belief of dream, way of thinking of reflection and being critical. [17] This view seems to underline the determination of the domestic/ household informants' social role. Critical attitude is emerged from reobedience and recollection of women's life experiences, which subsequently becomes a concentration (awareness). Concentration shows the clarity over what is hidden (gender) in real life. The awareness process encourages critical participation to make changes. So the factor of education determines women define the social role consciously.

The interpretation of religious values also underlies what social role is chosen by a woman. It is useful in conjunction with the psychological adjustment in terms of reducing the pressure of psychologically problems, the satisfaction of life and better self-actualization (where the personal potential is fulfilled). [18]

In structural and cultural perspective, the meaning of women's subjectivity is dynamic. Paulo Frier insisted that human life with its purpose is an event that establishes subjectivity and objectivity. Women subjectivity is dynamic subjectivity, in a continuum line between the pressure of mechanical objectivity, subjectivity and cultural dimension. [17] According to Archer, agency- structure dualism must be added to the cultural dimension to explain one's behavior. Because every human behaves is sociocultural. [16]. Further, women subjectivity is engaged in the interaction between the factors surrounded. Therefore, the women autonomy is relative.

Gender is predicted lead women running the essence of social role unconsciously, where the existence of gender oppression in all aspect of social life [19] is pervasive. It also makes women imperative with their double burden. [4] Gender oppression makes the meaning of the social role by women are dynamics as well as the diversity of conditions and the situation of women in gender relation. So, women subjectivity is still not stable in interaction and dialogue with elements of other covers [4]

According to Mackenzie, establishing and developing the subjectivity is able to increase the people autonomy directing their selves to live in self-hood and to evaluate how the women in the pressure of gender, defining symbols of oppression in relation personal are not equal to men. Autonomy describes the system capacity of a person and its functions, covering three dimensions which operates are relational. [20] The dimensions of self- determination, selfgovernment and self-authorization. Autonomy is the way strengthen the subjectivity of women to get on an awareness of progressive gender. Raising consciousness is a demand for the advancement - empowerment of women. [9, p. 113] Women with consciousness of gender has the intelligence of gender is important to address the pressures of gender subjectively. Empowering women first practical claims and 
then strategic one that is institutional and legal changes that support the status of women. [9, p. 118] According to the theoretical above, leading to the direction of the argument that subjectivity as an approach to the study of the role of social women needed to complete the approach that is used. The role of the social will be to give meaning to the efforts of equality of gender to do retrospect the policy previously.

\section{METHODOLOGY}

This study determined the informants purposively, namely female student who almost completing his studies, with a high achievement index. With a phenomenological approach, focusing the study on the ways informants act as agents of constructing social reality, the way to do this depends on how they give meaning to their own behavior. In-depth interviews looking for information include aspects of: knowledge or interpretation of gender discourse (gender roles), affection, trust or submissively due to subordination or to masculinity or femininity, expectations, motivation, and appraisal of religious values. Information subsequently analyzed with the perspective of gender to understand the perception reality of the woman social role, in giving meaning, conception, assumption, ideology and practice of the relationship just between the informant with men (husbands) [21]

These aspects are to analyze the extent to which the informant's capacity and the function system, in terms of the relative ability to shape one's own life, is not authentically directed by external manipulative forces, an agency competence and values or behaviors according to their own desires. Then achieve life development by reducing the obstacles of coercion, subordination to other parties. If aspects of it leads to progress with rated there is a tendency increasing autonomy of women who in essence is an increase in awareness (raising consciousness) is a requirement for advancement or empowerment of women. [9] This information is in accordance with Malcom's opinion that women as agents who carry out social construction through the process of participation in which they live [6].

\section{RESULT ANDDISCUSSION}

\section{A. Gender Traditional Role: Subjectivity and Gender Intelligence}

Data from interviews in general informants prioritize domestic areas or households as their social role by ignoring the objective structure. It is confirmed Ritzer's thought. [16, p. 518] Whereas the potential of informants plays a big role in the public domain due to their education. They interpret the tasks of the household, educate children and create comfort in the household, more important because of the issue of noble values. While the role of social public are oriented on the economy is positioned less important, an aspect of the material. For those nurturing is not only provide science knowledge but also the formation of morals and attitudes of children whose handlers its not easy to be entrusted to others. Indicated $\mathrm{Hb}$ "She is an educator main, associated with the husband of a wife that is good is that to obey, keeping his honor, his property, his family." The traditional domains of women are the two main areas of domestic work and child care [22]. Informants assume the job of households is substantially a task that remains "update", because the family for they are the foundation of building a social community. It was said by Dn: "...but the family must be prioritized ... I see that women are one of the assets of the nation to continue the next generation."

However, such as people who have the potential of professionalism - a career in the realm of public - still think progressively be chances that by utilizing technology to take part in the field of economics, so it remains to carry out the task of households with either. Perception of the role of social which thus can be said as meaning the " new " to the role of the domestic. Informants not only think in terms of evaluating modernity but think in a substantial way. It is showing the subjectivity of women strong decisive role.

Because education and reflection on his life experience informants respond to gender oppression in a variety of ways. They are sensitive to power and elements of domination. Most of them argue that the character of the masculine (male) is more superior and more competent as a leader. As delivered by HK: "And I believe that men more rational more intelligent than women; if women are smart because they are diligent, men conceptualize it as women who run it ". Most large as the stereotypes they argue that it is reasonable that the male dominant in the lives of family, social and institutional. Men who are having the character of masculine has the ability and strength to lead. Opinions are so mean they accept the stereotypes of masculinity. Expressed by Hk: "And I believe that men are masculine is more superior to the value of his character rather than women".

Affectively more of the informants refused or disagreed that the male masculine character was superior to the feminine-female character. They are of the view that the two characters are not binary, because both masculine and feminine characters are complementary, and need to complement each other to realize a higher quality of life. As Sy said: "Masculine and feminine characters are not much better than both because men and women have their respective portions."

Furthermore, they think it progressively build relationships gender (with husband) with autonomy which is expected to be optimal to give benefit together. By monitoring their life experiences all informants are convinced of their potential or ability as women, which in reality is partly like modelling their mothers facing the complexity of domestic life issues compared to those handled by men. This can be interpreted that the informant has a self- concept that is parallel and mutually beneficial in his gender relations. Or at least is proof of the informant's affection that does not approve of the superiority of masculinity over femininity.

But on the other hand, gender is considered as the values of cultural trust by informants, where they have experienced and known and lived since they were children in their daily lives. Gender values are believed to be the norm that has been practiced in their social lives as a 
stereotype.

Thought informants that vary to the pressure of gender mentioned in the above, indicate that the presence of the values of gender as the values of trust culture is empirical is dynamic. Personality imperative to unbelief cultural can be changed in line with changes in the way thinking and also a factor of social which manifests itself in the reality of life.

This stereotype is reinforced by the belief in the religious interpretation of informants Sy stated: "... But in the end, I followed my husband's orders because of religious values". This informant's view confirms the idea that religious beliefs regarding gender roles and family honor influence women's perceptions Williams \& Best, in [19]. Religiosity is useful in relation to psychological adjustment, because it connects to the problem of reducing psychological stress, life satisfaction and a better "actualization" of self (where there is full personal potential) [18].

Then, there are informants responding critically to religious interpretations, related to gender relations that do not benefit women. In stated H: "In a household of men have a mandate large to educate children and wife, but almost normative, is empirical not many men idealist like $i t^{\prime \prime}$. From the aspect religious interpretation as it indicates that the education of women has resulted in the ability to think critically.

From the results of interviews as described above, it clearly indicates the influence of the strong values of gender in terms of informants perceive the role of the social. One of the important indicators is the autonomy of decision -making the determination of the role of the social. Most of them declare autonomy are delivered or existing at the hands of her husband. It was stated by Sy and Hk: "If later I have a husband and if my husband forbids to work, then I will obey my husband even though the economic situation is lacking, because in religion the husband has the right to forbid us ..."

Gender as a cultural belief system affects the autonomy of the choice of the informant's social role. The choice of social roles must be compromised between with the husband through consultation, even though the decision is ultimately in the hands of the husband because the husband is the leader of the family. It was stated by Sy: "... be my strong desire if the husband does not approve and do not understand, I follow the husband as responsible because the values of religion should not oppose the husband's wishes."

In terms of the desire of the informant to convey decision making to play a role in the public sphere shows discursive awareness. With verbal-language disclosure the informant shows his awareness in the choice. However, there were informants who stated that autonomy in their own hands was better in married life, because they were consciously determined and thought of all the consequences so that if there were conflicts of gender relations. It was said by I: "The social role that I want to do is that the woman's free choice ... my career is as my self-actualization ..." In this context the informant's thoughts indicate his subjectivity in determining social roles.

\section{B. Women Social Role: Subjectivity and Gender Intelligence}

The tendency of the role of social informant in the realm of domestic is a role 's traditional that means not accounted for in the structure of the social as the role of the modern. Determination of the role of early social informants did not experience progress as defined by modernity - a role in the area of industrialization. The choice of domestic role can be interpreted by women as denying cultural resistance because the determination of their social role critically regards gender as a cultural belief system, even though its establishment is critical and with discursive awareness. This tendency has implications for the continuity of the role of women as educators of children and housewives, in other words, men are not idealized to play a major role in children's education in order to create a more harmonious life. Thus, the tendency of women's traditional gender roles has implications for the preservation of gender relations patterns. The pattern of gender relations that socially still positions women as subordination, results in a stagnant social status of women. According to Friedman, the status of women does not reflect the importance of the objectives of carrying out household tasks. [9] Factors structural and legitimacy of the social is not changed or affected by the implementation of the role of social traditional woman, because the status of socially defined as an objective - structural perspective [23].

But subjectivity female informant who is based on the substance of the role of traditional impact on the dynamics of the balance of the pattern is a relation such. Problems role of traditional women are progressive because awareness of the discursive, the capital strong to raise awareness of gender- process of socialization of primary to their children and are not directly socialization values of egalitarian (on understanding would urgency formation of the personality of the child) to the husband in the life of the household. It seems more possible to undertake efforts to strengthen the autonomy of women rather than avoid the pressure of gender [20]. Thus, institutional efforts and social processes need to foster gender awareness through gender education in the empowerment program of family institutions.

With gender education as population education (in the family) means increasing the status of women. The institutionalization of the functions of the institutional family can expand and create legitimacy social on the status of women related functions domestics. In summary, necessary efforts to create a system of assessment of new to the domestic functions as fundamental functions to the development of the character of the nation, a condition basis the progress of the nation. The internal structure of the household can be the basis of alternative development [9]

Gender education for men and women to foster gender intelligence, that is the capacity (cognitive, affective and behavior) to be intelligently responds to pressure gender norms, create the environment of social living that leading sustainability families. Higher understanding of gender discourse will be able to "get out" hidden things due to gender oppression, namely that both the masculine and feminine gender characters are complementary, not 
dominative. Additional strategic policy criteria are needed that give importance to women's autonomy in the technical policies that have been implemented so far. Subjectivity and gender intelligence will gradually give influence to the dynamics of the continuum lines of gender relations. The power that becomes the standard of this pattern of relations will move from certain aspects points towards the balance of relations, the foundation of gender equality.

substance of the strategic task of domestic. They belief the success of the education of children is the fulfillment of their expectations.

2. Factors of education in addition to the factors religiously affect the role of the which further fosters affection and how to think critically, to encourage the growth of autonomy and subjectivity

3. It takes additional criteria for policies that strategically gives meaning important for autonomic women at the policy technically that during this has been done .

\section{REFERENCES}

[1] A. J. Utomo, "Meninjau Kembali Tren Partisipasi Angkatan Kerja Perempuan di Indonesia," J. Peremp., vol. 23, no. 4, pp. 6-23, 2018.

[2] Badan Pusat Statistik, "Potret Pendidikan Indonesia Statistik Pendidikan Indonesia 2019," Jakarta, 2019.

[3] Badan Pusat Statistik, "Keadaan Angkatan Kerja di Indonesia Februari 2019," Jakarta, 2019.

[4] V. Burr, Gender and Social Psychology Focus, Tenth. London and New York: Routledge, 1998.

[5] Cakra Wikara Indonesia, "Lembar Fakta Agenda Politik Perempuan," Depok, 2020

[6] Z. Maliki, Rekonstruksi Teori Sosial Modern. Yogyakarta: Gajahmada University Press, 2012

[7] Databoks, "Jumlah Perceraian di Indonesia 2015- 2018," 2019

[8] A. Andini, "Pertengkaran dan masalah ekonomi: penyebab utama perceraian," 8 Desember, 2019. [Online]. Available:

https://lokadata.id/artikel/tingkat-perceraian-lebih- tinggi-dariperkawinan. [Accessed: 25-Apr-2020].

[9] J. Friedmann, Empowerment The Politics of Alternative Development. Massachusetts: Blackwell Pub Inc, 1998.

[10] Komnas Perempuan, "Catatan Tahunan Kekerasan Terhadap Perempuan 2019," Jakarta, 2019.

\section{CONCLUCION}

Of the overall description above, can be made a conclusion as follows:

1. The domestic social role, educating and caring for children and being a good wife becomes a fundamental social role for informants. Informants do the externalization not because gender role conformity but because the

[11] I. Abdullah, "Penelitian Berwawasan Gender dalam Ilmu Sosial," Humaniora, 2003.

[12] T. Hartini, "Pemberdayaan Ekonomi Perempuan: Keluar dari Kemiskinan,” J. Peremp., vol. 17, no. 3, pp. 65-81, Sep. 2012.

[13] leli Ruspita, "Keterasingan Perempuan dari Pekerjaannya: Kemitraan Suami-Istri dalam Pengelolan Keuangan Rumah Tangga," J. Peremp., vol. 17, no. 3, pp. 23-45, Sep. 2012.

[14] M. Thohri, "Perempuan dan Teologi Sosial (Studi Persepsi Perempuan Lombok Terhadap Kepemimpinan Perempuan)," Qawwam, vol. 9, no. 1, 2015.

[15] R. B. Burns, Konsep Diri Teori, Pengukuran, Perkembangan dan Perilaku. Jakarta: Arcan, 1993.

[16] G. Ritzer and D. J. Goodman, Teori Sosiologi Modern, Keenam. Jakarta: Kencana Prenada Media Group, 2010.

[17] P. Freire, Politik Pendidikan Kebudayaan, Kekuasaan dan Pembebasan. Yogyakarta: REaD fit. Pustaka Pelajar, 1999.

[18] Lumen Learning.com, "The Conflict Perspective on Religion,"

$$
\text { Lumen. [Online]. Available: }
$$

https://courses.lumenlearning.com/boundless- sociology/chapter/theconflict-perspective-on- religion/. [Accessed: 27-Nov-2018].

[19] A. Eagly H and (et. al), The Psychology of Gender. London: The Guildford Press, 2004.

[20] A. Veltman and M. Piper, Eds., Autonomy, Oppression, and Gender. New York: Oxford University Press, 2014.

[21] M. Fakih, Analisis Gender dan Transformasi Sosial. Yogyakarta: Pustaka Pelajar, 2008.

[22] G. Galliano, Gender Crossing Boundaries. Canada: Kennes State University, 2003.

[23] A. Syani, Sosiologi Skematika, Teori dan Terapan. Jakarta: Bumi Aksara, 2007. 